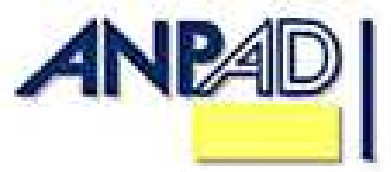

Available online at http://www.anpad.org.br/bar

BAR, Rio de Janeiro, v. 9, n. 3, art. 3, pp. 287-307, July/Sept. 2012

(c) EY-NC

\title{
Theorizing ICT and Society in the Brazilian Context: a Multilevel, Pluralistic and Remixable Framework
}

\author{
Marlei Pozzebon * \\ E-mail address: marlei.pozzebon@hec.ca \\ HEC Montréal \\ Montréal, Québec, Canada. \\ Eduardo Henrique Diniz \\ E-mail address: eduardo.diniz@fgv.br \\ Fundação Getúlio Vargas - EAESP-FGV \\ São Paulo, SP, Brazil.
}

* Corresponding author: Marlei Pozzebon

HEC Montréal, 3000, Chemin de la Côte-Sainte-Catherine, Montréal (Québec), Canada H3T 2 A7.

Copyright (C) 2012 Brazilian Administration Review. All rights reserved, including rights for translation. Parts of this work may be quoted without prior knowledge on the condition that the source is identified. 


\begin{abstract}
In this paper we present a multilevel and pluralistic conceptual framework that is particularly useful for Brazilian researchers investigating information and communication technology (ICT) based social changes from a community/societal level of analysis. The framework is influenced by three theoretical perspectives: social shaping of technology, structurationist view of technology and contextualism. It integrates four main concepts relevant social groups, interpretive frames, negotiation and technology-in-practice - organized in terms of three dimensions - context, process and content. The framework, already applied to 12 different research projects led by Brazilian scholars during the last four years, is seen as a work in permanent transformation and open to reuse, revision, remix and constant revalidation.
\end{abstract}

Key words: multilevel framework; Brazilian context; ICT and society; information system research; social technology. 


\section{Introduction}

For a number of reasons, countries like Brazil, Russia, India, and China (BRICs) are increasingly the focus of worldwide attention. Although the ultimate goal of most of that interest is commercial, related to expanding business activities and political relations, research also plays a part. Particularly in the ICT (information and communication technology) area, there are a growing number of publications targeting emerging and developing countries (Avgerou, 2008), and often, specifically the BRIC group. Most of the time, those publications have been written by researchers not native to, nor living in, those parts of the world. Brazil is no exception to this scenario.

Data from international studies on Brazilian academic production shows significant growth in the last two decades: from about three thousand articles published in Thomson Reuters indexed journals in 1989 to nearly twenty thousand in 2007. Thus, in relation to the overall scientific world, the percentage of articles with at least one Brazilian author jumped from $0.56 \%$ in 1989 to $2.02 \%$ in 2007 . Brazil now ranks thirteenth in publications, surpassing the Netherlands, Israel, and Switzerland (Regalado, 2010). As stated by the country's former Ministry of Science and Technology (Rezende, 2011), Brazilian academic production grew three times faster than the world average from 1982 to 2009. Despite being significant, these quantitative figures may not represent equivalent growth in qualitative scientific production since global impact of Brazilian science is still only $63 \%$ of the world average (King, 2009).

Since Brazil's academic output is currently highest in agricultural sciences, engineering, mathematics and physics, Brazilian management forums have recently been pondering evidence that IS research studies investigating ICT in the Brazilian context are not widely published internationally. Even if Brazilians occasionally appear as co-authors in some publications, researchers, research groups and leading international publications that focus on emerging or developing countries are most often affiliated with North American or European institutions. The special issue on Information Technology Research in Brazil published by the Journal of Global Information Technology Management, in April 2009, seems to be an exception, with a fully Brazilian-authored group of articles published in an international journal.

This might suggest that Brazilian IS researchers are not very active in producing knowledge about development and technological change from the perspective of their own context. However, a quick look at Brazilian IS research production shows that national and regional conferences in the management area are proliferating and that ICT occupies an important position. The most relevant examples are: the ADI (Administration of Information) track at ENANPAD (the annual conference of the Brazilian Academy of Management) and ENADI, a biannual IS conference in which a growing number of Brazilian IS researchers take part. There are also a number of Brazilian journals focused on management in general, and even some on ICT in particular, demonstrating consistent quantitative growth in academic production in the area.

In addition to extant locally published academic production, evidence suggests that the vast Brazilian territory is becoming a correspondingly huge laboratory for ICT-related social and business innovations, with an increasing number of studies of ICT innovation experiences being reported (Avgerou, 2008). This represents a priceless opportunity for researchers concerned with organizational and social implications of ICT to develop further research programs in the Brazilian context. In the particular case of Brazil, notable areas featuring innovative use of ICT are: government and public administration (Barbosa, 2008), banking technology (Diniz et al., 2009a), digital inclusion (Lemos \& Martini, 2010), mobile use (Saccol, Manica, \& Elaluf-Calderwood, 2011) and e-democracy (Cunha \& Pozzebon, 2009), among others.

In this paper we present one view of theorizing on ICT and society through a conceptual framework that has been influential in recent Brazilian research focusing on ICT-based change at the community/society level of analysis. The framework is multilevel, pluralistic and remixable, in the sense that it is being appropriated and adapted by IS researchers in Brazil and collectively transformed 
and rebuilt. It is important to note that although we argue that remix and mash-ups are part of Brazilian culture and are reflected in academic activity as well, the framework presented in this paper can also be adapted by researchers from other regions. This can be considered particularly true for situations where innovative incorporation of new technologies that were first created and disseminated in developed countries, such mobile phones, are opening up new ways to understand social implications of ICT.

\section{Brazil, a Fascinating Laboratory of ICT Innovation}

A number of ICT innovations exemplify how the use of ICT in Brazil over the last decade has opened up opportunities for creating original research in the IS field. In 2010 Brazil joined the group of countries with more than one cell phone subscription per inhabitant, and Internet access by the lowincome population has grown significantly: despite government investment in free access telecenters, it is the LAN house phenomenon - small facilities that provide internet access at affordable rates - that is responsible for increasing Brazil's connectivity level without any specific public policy being directed towards it. A report from the Brazilian Internet Steering Committee reveals that more than $70 \%$ of the poorest population segment access the Internet through one of the more than 90,000 LAN houses spread across the country, compared with only 5\% that do so at government telecenters (Comitê Gestor da Internet no Brasil [CGI], 2010). L. A. Silva and Gushiken (2010), by mapping the distribution of points for Internet access in the outskirts of a Brazilian capital, show how the LAN houses represent a constant reinvention of social actors from the low-income stratum entrepreneurially appropriating a modernity not designed for them. The LAN house phenomenon is creating new forms of social and economic interaction, and new emerging and open business models, whose impacts and consequences are still largely unknown.

Brazilian banking technology has also proved to be innovative in its use of ICT. The correspondent banking model was put in place to provide the low-income population with access to financial services all over the country (Diniz et al., 2009a). A report from Brazilian Banking Federation (FEBRABAN) indicates that the 150,000 correspondent points in the country account for $6 \%$ of all banking transactions. Correspondent banking is also the fastest growing bank channel, serving mostly the poorest and most remotely located populations (Federação Brasileira de Bancos [Febraban], 2010).

Applications like electronic voting and income tax declarations via the Internet have attracted international attention since the 1990s; either, as in the former case, because of the level of efficiency or, as in the latter case, because of the millions of people involved. The Brazilian voting system is noteworthy, with Brazil being the only country in the world where a fully electronic ballot is the means by which over 100 million voters choose their representatives every two years in a simple, fast and transparent way, an important instrument helping to enhance democracy in the country (Saccol et al., 2011). As pointed out by Avgerou, Ganzaroli, Poulymenakou, and Reinhard (2009, p. 135), the electronic voting system of Brazil is seen as a "trustworthy mechanism of producing election results that accurately represent the choices of the electorate". The transition to electronic voting has also affected what kinds of politicians are elected, reducing the capacity of political machines to manipulate electoral outcomes, thus "benefiting candidates of Brazil's major national parties, who tended to rely less on local machines to win votes through fraud", as mentioned by Hidalgo (2010, p. 1).

UNESCO's 2010 report on Creative Economy identifies some Brazilian innovations as noteworthy, particularly those related to the creative commons movement. Formally initiated in Canada and the US, the creative commons has found one of its biggest exponents in Brazil. Proposing a new way of dealing with intellectual property, particularly with regard to digital culture (all cultural artifacts that can be digitized, like music, photos, videos, images, drawings, paintings, texts), creative commons represents the freedom of collectivity, which benefits from knowledge and art, creation and recreation (Leal \& Souza, 2010). Books, cases studies and reports centering on ICT-related 
phenomena are being published with focus on the music industry, where movements like techno-brega and funk are explored to illustrate the potential of open business models (Lemos \& Castro, 2008).

The last but not the least important illustration is the work being developed around themes like social technologies (Dagnino, 2009) and social residence (Fischer, Roesch, \& Melo, 2006). This stream of research reflects an increasing concern with designing technologies for social inclusion and is guided by a pragmatic approach that is interdisciplinary, problem-oriented, and policy-oriented in nature (Dagnino, 2006; Instituto de Tecnologia Social [ITS], 2011). Significant Brazilian participation in social networks (Ahmad, 2011) and the impressive growth rate of Brazilian e-commerce, already accounting for almost 30 million online customers (Webshoppers, 2011), are representative of the country's insertion into the digital economy and of the remarkable opportunities to be better explored by Brazilian researchers.

Despite the fact all these innovative transformations through ICT in Brazil have been investigated, examined, published, debated and contested, they have not yet been taken notice of by most of the international IS community. Pozzebon, Diniz and Reinhard (2011), presenting a number of reasons why Brazilian researchers are not successful in being published internationally, emphasized that language remains the first and foremost barrier. A second undeniable factor is that Brazilian researchers are rarely active in leading academic networks or on the editorial boards of international journals, particularly the most prestigious ones.

A third challenge for the internationalization of Brazilian IS research, according to Pozzebon et al. (2011), arises from the fact that Brazilians often perceive the relevance of the substantive aspect (the subject under study) as more important than the pure theoretical aspect (the perspective adopted in examining the subject being studied). That prevalence of relevance over other criteria goes against the dominant logic of leading international outlets, which place huge weight on a certain style of theorizing in form and content (Avgerou, 2008; Walsham \& Sahay, 2006). This does not necessarily fit with the rationality of researchers from Brazil, and other developing countries, who struggle to format their ideas according to required external logic (emanating mostly from the US and Europe). Despite this preference and taste for relevant and pragmatic writings, clear advances are being made in the theorizing vein. Efforts to increase theoretical and methodological robustness according to international standards are already in place in Brazil, as shown in EnANPAD and the top Brazilian journals, and these efforts are being strengthened in order to allow for the emergence of an internationally respected Brazilian school of IS research.

In the next section we present a multilevel, pluralistic and remixable theoretical framework that was conceived by Brazilian researchers and is being applied and transformed by a group of scholars working on ICT-based innovations at the community/societal level. We consider this framework as a contribution to helping researchers either from Brazil or from other countries.

\section{A Multilevel and Pluralistic Conceptual Framework}

The framework we present here was conceived in 2004 to guide a team of researchers working around two research programs: (a) ICT and financial inclusion and (b) ICT and local and sustainable development. It was published primarily as a book chapter in 2009 (Pozzebon, Diniz, \& Jayo, 2009) and it was then progressively applied, refined and transformed by different scholars. By December 2011, the framework had already been applied in 12 different research projects and more than 30 publications, including peer-reviewed papers, proceedings, doctoral and master's dissertations. The common point in all these studies, besides interest in ICT and social issues, is the level of analysis: community/society.

The meaning of community would merit a separate discussion in itself, and a huge variety of definitions can be found in the literature (e.g., geographic communities, communities of culture, 
communities of interest, international community, etc.). In this paper, we adopt the concept of community/society as it has been traditionally defined in sociology: a group of people sharing a common geographical or virtual territory who have something in common (e.g., values or interests) or who are actively engaged with one another in some manner. Those people interact in networks and can participate in coalitions, teams, organizations, associations (Putnam, 2000). We see this conceptual framework - multilevel and pluralistic - as a work in permanent transformation and open to reuse, remix, revision and revitalization.

\section{Inextricably linked levels of analysis, from individuals to community/society}

The importance of studies at the community/societal level is rising, as researchers worldwide become more aware that, as a society, we will be incapable of dealing with important issues such as social welfare, social equity and sustainability if we continue to focus merely on doing what we are currently doing more efficiently, research included. New forms of social and economic relations as well as new ways of balancing human needs and natural resources are likely to emerge (L. Silva \& Westrup, 2009). These needs transcend those organizational problems that IS researchers have traditionally focused on: productivity, performance, risk, satisfaction and other constructs related to the impact of IT at the individual, organizational or inter-organizational levels. Although these areas remain relevant, their dominance has overshadowed other themes and levels of analysis and the dynamics of ICT at the community/societal level remain comparatively ill-defined and underresearched.

The conceptual framework presented in this paper is multilevel because it incorporates three inextricably linked levels of analysis: individual, group and community/society. In line with BurtonJones and Gallivan (2007), we apply the term multilevel to a type of framework that entails more than one level of conceptualization and analysis. However, we differ from the latter authors with regard to ontological stance. While they place multilevel research within a perspective that adopts a functionalist, positivist and variance-oriented approach, we place the current multilevel framework within a constructivist tradition that views any social research as processual and inherently multilevel.

In brief, there are opportunities for IS research to address the relationship between ICT and people in broader contexts than just the specific organizational setting. Greater effort should be made to "broaden the scope of IS research from its traditional focus on phenomena associated with computer-based information systems at the individual, group, and organizational levels, to address the broader institutional and social developments in which IS are increasingly implicated" (Jones \& Karsten, 2008, p. 150). The emergence of theoretical frameworks that address these levels should help to resolve the current imbalance. In this light, the conceptual framework proposed here is particularly useful for research involving complex and multilevel interactions between individuals, groups, organizations and networks at the community/societal level, struggling to implement and utilize ICT innovations for change and developmental purposes.

\section{Theoretical pluralism}

The second feature of the conceptual framework (Table 1) is theoretical pluralism, as it has been influenced by three theoretical perspectives: contextualism, social shaping of technology and structurationist view of technology. Indeed, contextualism and its three dimensions - context, process and content - is the frame in which four main concepts, selected from social shaping of technology and the structurationist view of technology, are integrated: (a) relevant social groups, (b) interpretive frames, (c) mechanisms of negotiation and change, and (d) technology-as-practice. Table 1 presents the main components of the framework. 
Table 1

The Main Components of the Framework

\begin{tabular}{lll}
\hline Dimension & Concepts & \\
\hline Context & $\begin{array}{l}\text { Social groups (link between individual and community) } \\
\text { Interpretive frames }\end{array}$ & Social shaping of technology \\
Process & Mechanisms of negotiation & \\
Content & Technology-in-practice & Structurationist view of technology \\
Contextualism & & Theoretical perspective \\
\hline
\end{tabular}

\section{Framing the frame: adopting a contextualist approach}

The first theoretical influence on our conceptual framework comes from the contextualist approach, which was first introduced by Pettigrew $(1985,1987,1990)$ and has gained significant attention among IS researchers (Augustsson, Nilsson, \& Holmström, 2010; Ngwenyama, 1998; Walsham, 1993). Arguing that much research on organizational change was non-processual and noncontextual in character, Pettigrew $(1985,1990)$ emphasized three elements: context, process and content. Pettigrew claimed that these three elements are equally important and should be considered in concert.

Contextualism is depicted in IS research as a theory (Karyda, Kiountouzis, \& Kokolakis, 2005), as a methodology (Walsham \& Sahay, 1999) and as a type of organizational change framework (Klein \& Myers, 1999). Despite these different ways of referring to contextualism, all the IS studies reviewed emphasize similar properties of such a theoretical foundation: it allows detailed examination of actions and perceptions of human actors without neglecting the historically situated context within which these actions take place and perceptions are formed (Walsham \& Sahay, 1999). As Pettigrew (1990, p. 269) explains, when applying a contextualist lens, we look for "continuity and change, patterns and idiosyncrasies, the actions of individuals and groups, the role of contexts and structures, and processes of structuring" over time.

Adapting context, process and content to investigations of ICT-based change at the community/societal level, we consider that: (a) the context refers to the social setting where the ICT artifact is being implemented and used. It helps define the boundaries of the investigation and includes identification of different relevant social groups interacting in a given social and cultural setting. It also includes identification of interpretive frames for each social group, allowing the recognition of shared and conflicting perceptions, expectations and interests that characterize the community context; (b) the process refers to understanding how social groups (and their frames) influence the negotiation process taking place around the implementation and use of a given ICT artifact. The how implies recognition of mechanisms open to negotiation and change; and (c) the content refers to the resulting socio-technical characteristics of the ICT artifact being implemented, as used by particular actors at a given level of analysis (individual, social groups, community/society). The technologies-inpractice resulting from the process of negotiation are considered here, with an understanding of the resulting consequences, both intended and unintended.

\section{Integrating a social shaping view of technology}

The three first concepts integrated in the context and process dimensions - namely social groups, interpretive frames and mechanisms of negotiation - come from a stream of research known as social shaping of technology, which can be divided into two broad categories: socioeconomic shaping of technology (e.g., MacKenzie \& Wacjman, 1999; Williams, 1997) and social construction of technology (SCOT) (e.g., Bijker \& Law, 1992; Pinch \& Bijker, 1984), the latter category being strongly influenced by sociology of knowledge (Berger \& Luckmann, 1967). The 
social shaping view pays special attention to the diversity of actors' interpretations of the meaning and content of technology and emphasizes the identification of opportunities where decisions and actions regarding technology management and change may be undertaken (Clausen \& Koch, 1999; McLoughlin \& Harris, 1997; Wilson \& Howcroft, 2005). Worthy of note is the strong influence that social constructivism approaches have exercised on Brazilian literature concerning social movements and local development. The concept of social technologies, as previously described, is one of the translations of this stream of literature that have influenced our research. In the following paragraphs, we describe in detail these three seminal concepts of our framework which have been borrowed from the social shaping view.

1. Identifying social groups: In order to take into account a broad, complex and heterogeneous network of diverse actors interacting in a given community or region, we found it crucial to begin any investigation with the identification of the different social groups interacting within the boundaries of the phenomenon of interest. Relevant social groups, or simply social groups, refer to a group of people who share a common geographical space (e.g., a small neighborhood), a common social class (e.g., low-income population in a neighborhood or a city), a common professional occupation (e.g., nurses in a hospital setting), etc. In addition, from a constructivist point of view, relevant social groups also share a set of assumptions about a given subject of interest, for example, the expected benefits of the implementation of a new technology (Sahay \& Robey, 1996). Subgroups, alliances or coalitions among social groups form social spaces that shape the choices of implementation and use of any kind of technology (Clausen \& Koch, 1999; Koch, 2000). This critical and political view of social groups is in line with Bartis and Mitev (2008), who emphasize the differences in power relationship and the interplay of interests and conflicts of different coalitions in a given context.

2. Identifying competing or convergent interpretive frames: The assertion that people within a social group are likely to share a set of assumptions leads to the concept of interpretive frames. People act in the world on the basis of how they interpret and re-interpret it. The concept of interpretive frames (Bartunek \& Moch, 1987) is similar to those of interpretive schemes (Bartunek, 1984; Giddens, 1984), technological frames (Orlikowski \& Gash, 1994), mental models (Argyris \& Schon, 1978), provinces of meaning (Ranson, Hinings, \& Greenwood, 1980; Weick, 1993), cognitive maps (Eden, 1992) or simply frames (Goffman, 1974). Interpretive frames are mental models that shape people's interpretations, influencing their actions and decisions. Interpretive frames refer to basic assumptions, beliefs, and expectations that people hold about a specific technological application (Davidson, 2002, 2006), including not only the nature and role of the technology itself, but the specific conditions, applications and consequences (intended and unintended) of that technology in particular contexts (Orlikowski \& Gash, 1994). They might represent competing or converging accounts, which can be related to competing or converging interests regarding the outcomes of the implementation of a new technology. McLoughlin, Badham, and Couchman (2000, p. 20) make reference to "frame dominance" and "competing accounts". Similarly, Ranson, Hinings, and Greenwood (1980, p. 1) propose that people create "provinces of meanings," which represent the basis of their orientation. Although individually held, those frames are articulated with value preferences and sectional interests that are shared across groups (Gallivan, 1996). The more congruent the frames of different groups are, the greater the chances that the implementation and use of ICT will be successful (Lin \& Silva, 2005). The resolution of competing frames hinges on dependencies of power and domination. In other words, the results of conflict among social groups holding conflicting perspectives will depend, in part, on the comparative power of these groups to make their perspective heard (Ranson et al., 1980). Frames of meaning always incorporate power differentials.

3. Identifying mechanisms open to negotiation and change: The implementation of a new ICT in a community or region can be seen as an opportunity to change information flow, resource allocation and responsibility attributions. "IS are drawn on to provide meaning, to exercise power, and to legitimize actions" (Walsham, 2002, p. 362). For this reason, by implementing a new ICT, people can reproduce, transform, adapt and even reinvent their daily practices. Social shaping studies 
outline opportunities in which technology can be interpreted, reinterpreted and negotiated in different ways. Aiming at overcoming the rather deterministic conception of technology often found in mainstream technology management literature, which tends to take technology for granted as a well-defined tool (Dawson, Clausen, \& Nielsenet, 2000), social shaping studies view technology implementation as the outcome of social processes of negotiation between networks of social actors. The identification of occasions, or spaces where mechanisms open to negotiation and change, becomes crucial to our research practice. We focus on the process of negotiation, where not only the content of the technology itself, but also the different interests, commitments, perspectives and positions of the network of social groups interacting with the technology will influence the process and outcomes of technologies-in-practice and the emergent social structures.

\section{The contribution of a third perspective: the structurationist view of technology}

The third theoretical influence on our frame is the structurationist view of technology, which represents one of the streams within IS research claiming to apply Giddens' structuration theory. It encompasses the work of authors like Barrett and Walsham (1999), Heracleous and Barrett (2001), Montealegre (1997), Ngwenyama (1998), Nicholson and Sahay (2001), Olesen and Myers (1999), Orlikowski (2000), Pozzebon and Pinsonneualt (2005), Sahay (1998) and Walsham (2002). Among the several concepts put forward by these studies, one exhibits a strong fit with our underlying assumptions and it was integrated into our frame: technology-in-practice.

4. Identifying intended and unintended consequences of technologies-in-practice: Our view of technology-in-practice emphasizes the role of emergence and improvisation. The focus is on the enactment of technology, noting that there are always boundary conditions on how people can (even if they do not) redefine the meaning, properties and applications of a given technology during and after implementation, and allowing a better understanding of the emergence or non-emergence of new social structures (Orlikowski, 2000). This helps to explain our focus on local or community adaptations or appropriations: how social groups, negotiating meaning, properties and applications of a given ICT, locally adapt them, and what are the consequences (intended or unintended). Different cultures will engage differently with local adaptations or appropriations. We need to understand the particular ways in which people engage with these processes as they are likely to be culture-dependent. Regarding the Brazilian case, we found in the concept of improvisation an insightful fit with the concepts of negotiation and technology-in-practice. The concept of improvisation has drawn the attention of several researchers investigating IT-based organizational change (Bada, Aniebonam, \& Owei, 2004). It may emerge for several reasons: from emergency situations or crises (Weick, 1993); in response to managing unexpected opportunities or breakdowns during the process of implementing change (Orlikowski \& Hofman, 1997); from unexpected action rooted in intuition and aimed at resolving particular situations or crises (L. Silva, 2002); and from intentional actions, intuition and sensitivity to everyday practices and experiences, or what Ciborra (1999) calls smart and competent improvisations.

L. Silva (2002) has argued that improvisations are frequent in developing regions because of the less stable political and economical environment, and this point is valuable in understanding the Brazilian context. However, a variety of other cultural aspects should be taken into account. For example, ambiguity is seen as an essential trait in Brazilian culture. "In Brazil nothing is what seems to be, and when it is what it seems, it can also be something else. To deal with this ambiguity, Brazilians disguise it as flexibility or adaptability" (Caldas \& Wood, 1997, p. 7). A typical manifestation of this quality is the well-known Brazilian way, or jeitinho brasileiro, which means that there is always a way of solving problems in ways that are not expected or institutionalized. The Brazilian way comprises all social practices that attempt to find a way around rules and, according to many authors, it constitutes a social strategy to soften the impersonal forms which govern Brazilian personal relations (DaMatta, 1989). Therefore, as illustrated later, the pluralist framework has been applied in a way that is in line with Brazilian culture. 


\section{A Framework in Constant Metamorphosis: Empirical Illustrations}

In brief, the framework is pluralistic as it combines contextualism, social shaping of technology and structurationist view of technology. It is multilevel because it incorporates three inextricably linked levels of analysis: individual, group and community/society. It combines four central concepts: social groups, interpretive frames, mechanisms of negotiation and technology-in-practice. These concepts are linked according to three interconnected dimensions, as posited by contextualism: content, context and process. Figure 1 illustrates the framework.

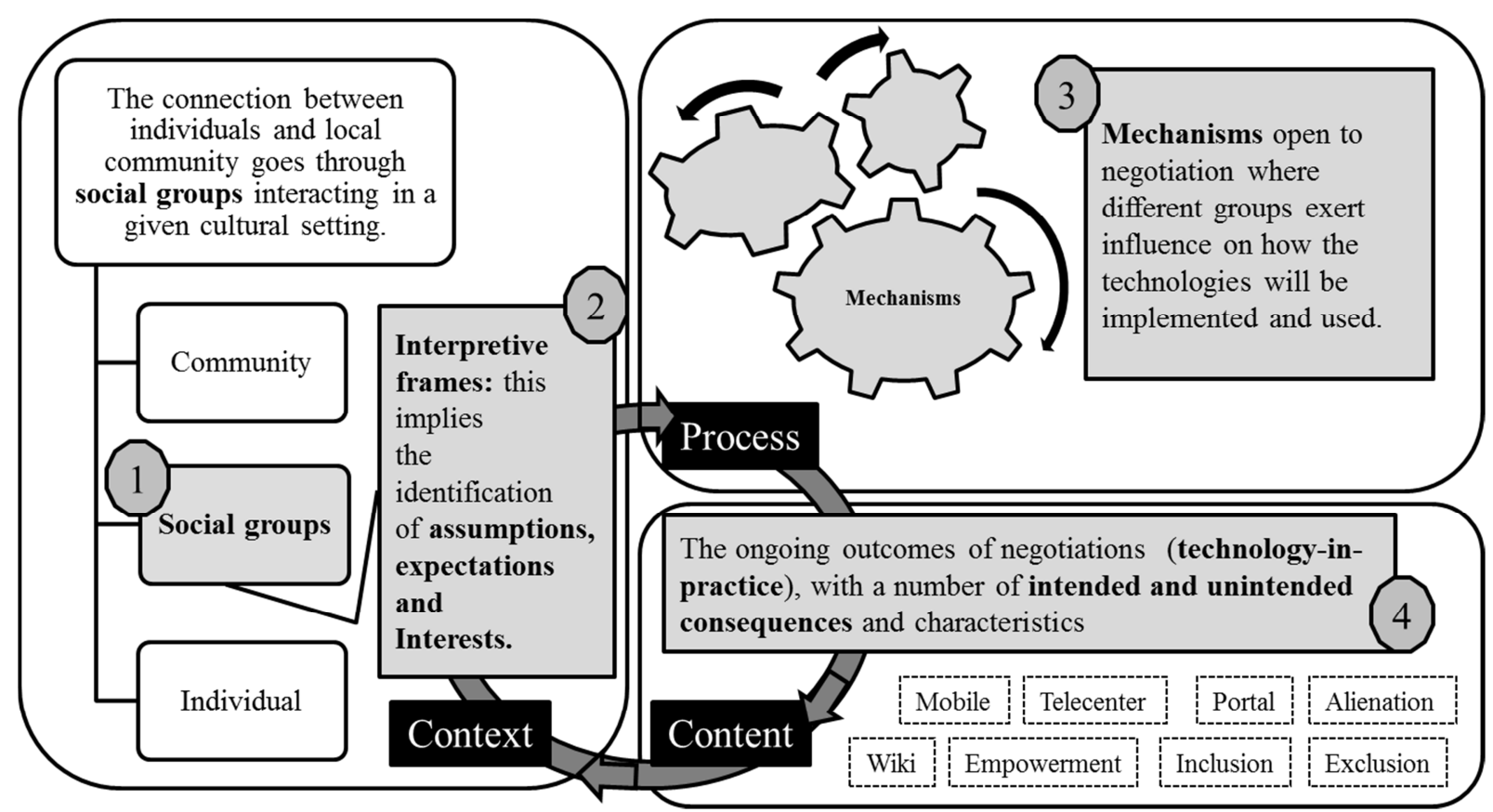

Figure 1. A Multilevel and Pluralistic Conceptual Framework.

We call this a conceptual framework for analytical induction because no hypotheses or propositions are offered but only a frame with concepts that will guide the empirical work. The goal is to start with a general theoretical model and to distill such a model within an iterative process that does not take the initial model for granted but allows us to recognize new categories and refine existing ones in such a way as to enrich our understanding of the research problem (Patton, 2002).

Table 2 reports the 12 research projects where the framework has been applied as the guiding theoretical lens, presenting the studies, their main purpose, and the way the framework was applied, with a summary of the adaptations proposed. 
Table 2

\section{Empirical Studies Applying and/or Transforming the Theoretical Framework}

\section{$\begin{array}{lll}\text { Studies } & \text { Research subject } & \text { Main contribution to the framework }\end{array}$}

Diniz, Pozzebon, Diniz and Pozzebon pioneered the use of and Jayo (2007a,b; the model in the Brazilian context. They 2008; 2009a, b); $\quad$ have been applying the frame to build Diniz, Birochi, and knowledge around an important ICTPozzebon (2010) related phenomenon: financial inclusion and the Brazilian correspondent banking (CB) network.

Barbosa (2008)

Barbosa investigated the process of performance evaluation of e-government platforms from a citizen perspective.

Figueiredo (2009) Figueiredo studied the process of negotiation behind the definition of standards of digital TV in Brazil, trying to understand political and strategic associations needed to establish a single technological standard in a situation where important social groups were organized to defend different standards to support their own particular interests.

Luvizan (2009) Luvizan studied the deployment process of a human resource management system in an organizational context.

Yokomizo (2009); Yokomizo, Diniz and Pozzebon (2009)

Delgado and Pozzebon (2010); Pozzebon, TelloRozas and Delgado (2012)

Yokomizo investigated the complex process of growth, consolidation and late merger of a "virtual" bank, originally conceived of as a $100 \%$ branchless model, and its operation based on close alignment with network integrators.

The researchers applied the framework to understand the implementation of a GIS (geographic information system), through the use of participatory practices, in a Mexican community.

Jayo (2010)
Jayo developed a taxonomy for network integration management for correspondent banking in Brazil. He explains how different models have emerged in the historical process of implementation, and he identifies limits and potentials for different models of financial services to low-income populations.
The authors used the model to guide a research program on ICT and financial inclusion. A number of in-depth case studies were carried out using the framework as the conceptual lens. A crosscase analysis of all the cases is currently being developed.

The author applied the framework as is.

The novelty of the use of the conceptual framework was methodological in nature: the author applied the model in a retrospective analysis and based on secondary data.

The author adapted the model to an organizational level of analysis, particularly considering the diversity of actors and related interests involved in the process of implementing a new ICT.

The author applied the model as is, putting emphasis on understanding of the negotiation process among social groups involved in building a particular business model.

The authors enriched the first dimension of the frame - the context - by proposing two levels: an institutional level, where the laws, culture, politics and history of the community should be clearly depicted, and an interactional level, where they suggest the identification of skills and tools in place.

The author transformed the framework in order to take into account more complex environments at a national level. He expanded the second dimension of the frame - the process - by proposing that the same social groups might be involved in several parallel negotiation processes, in different combinations. 
Table 2 (continued)

\begin{tabular}{|c|c|c|}
\hline Studies & Research subject & Main contribution to the framework \\
\hline Cernev (2010) & $\begin{array}{l}\text { Cernev analyzed the mobile banking } \\
\text { phenomenon in the Brazilian context, } \\
\text { intending to describe future scenarios for } \\
\text { adoption of cellular phones in the Brazilian } \\
\text { banking market. }\end{array}$ & $\begin{array}{l}\text { The author incorporated multiple scenario } \\
\text { theories in the model - particularly the } \\
\text { context dimension - to expand its } \\
\text { possibilities in understanding future } \\
\text { situations, based on possible articulations } \\
\text { of social groups. }\end{array}$ \\
\hline $\begin{array}{l}\text { Lavoie }(2010) \text {; } \\
\text { Lavoie and } \\
\text { Pozzebon }(2010) \text {; } \\
\text { Lavoie, Pozzebon, } \\
\text { and Gonzalez (2011) } \\
\text { (research project) }\end{array}$ & $\begin{array}{l}\text { Lavoie applied the framework to } \\
\text { investigate the transfer of microcredit } \\
\text { methodologies from one context to } \\
\text { another: first, from Grameen (Bangladesh) } \\
\text { to Crediamigo (in the north of Brazil) and } \\
\text { them from the North of Brazil to other } \\
\text { regions (South and Southeast). }\end{array}$ & $\begin{array}{l}\text { The author carried out an adaptation of the } \\
\text { concept of technology-in-practice, } \\
\text { proposing the concept of methodology-in- } \\
\text { practice, and the recognition of core and } \\
\text { secondary features of methodologies-in- } \\
\text { practice, which are useful in situations } \\
\text { where transfer is in play. }\end{array}$ \\
\hline $\begin{array}{l}\text { Birochi (2011); } \\
\text { Diniz et al. (2010) }\end{array}$ & $\begin{array}{l}\text { Birochi investigated, from a critical } \\
\text { perspective, the implementation of a } \\
\text { distance learning systems for microfinance } \\
\text { education in remote locations, seeking to } \\
\text { help in the process of emancipation of poor } \\
\text { microentrepreneurs. }\end{array}$ & $\begin{array}{l}\text { The author applied the model as a } \\
\text { preliminary pilot study, i.e., as a strategy to } \\
\text { understand the context, process and } \\
\text { content of a remote location, in order to } \\
\text { collect enough data and start a second } \\
\text { phase of the field work, where a second } \\
\text { framework - critical - was applied. }\end{array}$ \\
\hline Gabarra (2011) & $\begin{array}{l}\text { Gabarra analyzed the recent introduction of } \\
\text { the Mobile Virtual Network Operation in } \\
\text { Brazil, aiming to identify adequacy of } \\
\text { Brazilian regulation for business objectives } \\
\text { of the main social groups involved. }\end{array}$ & $\begin{array}{l}\text { The author applied the model as is, the use } \\
\text { of the model allowed for the understanding } \\
\text { of social group interactions and the } \\
\text { identification of possible main players in } \\
\text { the future. }\end{array}$ \\
\hline Moreira (2011) & $\begin{array}{l}\text { Moreira investigated potential of } \\
\text { correspondent banking outlets to offer } \\
\text { transactional services other than financial } \\
\text { services, such as tickets, coupons, games, } \\
\text { transportation vouchers, etc. }\end{array}$ & $\begin{array}{l}\text { The author enriched the third dimension - } \\
\text { the content - by showing the multiple } \\
\text { possible technological configurations built } \\
\text { from the social construction of the multiple } \\
\text { network connections between banks, } \\
\text { network integrators and correspondent } \\
\text { outlets. }\end{array}$ \\
\hline
\end{tabular}

In order to illustrate the progressive process of appropriation and transformation of the conceptual framework, we selected three studies that have, respectively, brought important adaptations to each of the three dimensions of the contextualist frame: adaptations to the context, the process, and the content.

First, regarding the context dimension, we selected the research project carried out by Pozzebon, Tello-Rosas and Delgado (2011), called Sierra Nevada project. This is the only research project using the conceptual framework that was carried out outside Brazilian borders. The goal of the project was to understand the social consequences of the implementation of a geographic information system (GIS) in a small municipality - Talmanalco - $100 \mathrm{~km}$ from Mexico City. The GIS was adopted and deployed by a neighborhood association of Talmanalco with the goal of helping the inhabitants, the majority low-income, in managing their natural resources.

The multilevel frame proposes the identification of individuals living in a given community (e.g., local people living in a small Mexican town) where a given ICT application is being implemented (e.g., a GIS). Between individuals and community, social groups are identified so as to conceptualize and make sense of how people interact within a given community, whether individually 
or as part of an association, an entity or a network. Four main social groups were identified: university researchers, governmental authorities, the GIS team project and a community association (Delgado \& Pozzebon, 2010). To each social group, the authors applied the concept of interpretive frames, enabling them to recognize what kind of interests, assumptions and expectations those different groups were attaching to the adoption and use of the GIS. Convergence or divergence, and dominance and conflict among interpretive frames revealed important mechanisms of the negotiation among social groups. These two concepts - social groups and interpretive frames - helped to define the initial boundaries of the investigation and to establish the context in which the use of ICT will produce intended and unintended consequences.

The first adaptation proposed by the authors was to extend the scope of the context dimension. They organized the two initial concepts - social groups and their respective frames - into an interactional level of the context, and they suggested the integration of two new concepts - skills and tools. Therefore, for each social group, in addition to the interpretive frames, the authors identified what skills were in place and what tools, in addition to the GIS being implemented, were mobilized. This provided a richer picture of social groups, with a clearer understanding of their weaknesses and strengths. The second contribution of the authors was to explicitly integrate the institutional level into the context; which means the building of a historical account of the phenomenon under investigation, including the regulatory and cultural aspects that could contribute to a deeper understanding of the context (Pozzebon, Tello-Rozas, \& Delgado, 2012).

Second, regarding the process dimension, we emphasize the contribution brought by Jayo in his thesis dissertation. In order to develop a taxonomy for the phenomenon known as correspondent banking network integration, Jayo (2010) proposed an important change in the process dimension: to take into account multiple processes of negotiation evolving simultaneously and, most of the time, involving the same social groups in different arrangements. Political issues and power dependencies became clearer using this approach, where not only the negotiations directly related to the implementation of banking and telecommunication technologies were included in the analysis, but also other related negotiations, e.g., national regulations of the network.

Regarding the identification of mechanisms open for negotiation, we believe that future research should include emergent action-based lenses in the examination of the negotiation phase. Theoretical approaches like negotiated order (Heracleous \& Marshak, 2004), situated-action (Ciborra \& Willcocks, 2006) and actor-network (Pentland \& Feldman, 2007) could be of great value in providing operationalized concepts that help to recognize, as the contextualist approach prescribes, the details of actions and perceptions without neglecting the richness of historically situated contexts.

Finally, regarding the content dimension, we outline the work of Lavoie (2010), who carried out an in-depth case study on the transfer of microcredit methodologies from one context to another. The author investigated the beginning and evolution of Crediamigo, today the biggest Brazilian microfinance institution. The microcredit methodology applied by Crediamigo was originally influenced by Grameen Bank (Yunus, Moingeon, \& Lehmann-Ortega, 2010) and was adapted to context of the Brazilian Northeast, one of the poorest regions in the country. With the successful deployment of Crediamigo branches in several Northeast localities, Crediamigo's top management started to plan its implementation in other regions of Brazil, mainly the Southeast. Trying to identify the conditions for this replication, Lavoie proposed an adaptation, applying the concept of technologyin-practice to a better understanding of the resulting methodology (once transferred and adapted), and proposing the concept of methodology-in-practice.

Figure 2 shows the framework up to 2011, originally conceived in 2004 and transformed in varying degrees by those 12 research projects, with some of the proposed adaptations. 


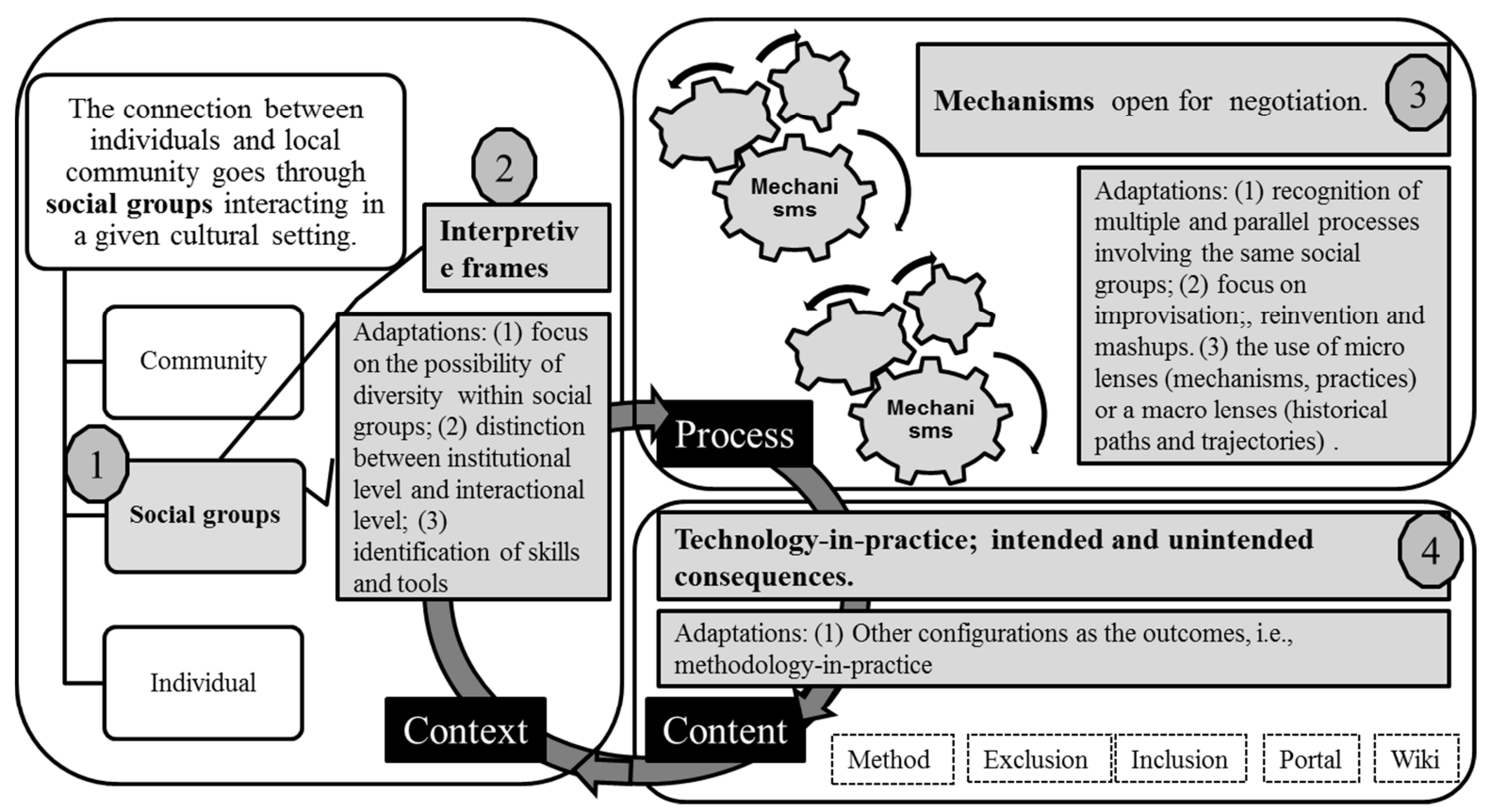

Figure 2. The Conceptual Framework with Proposed Adaptations.

\section{Conclusions}

As the influence of ICT on social life broadens in scope and heterogeneity in terms of actors involved, diversity of interests and technological views, IS researchers need to rely on conceptual approaches so as to build a multilevel understanding of the technological phenomena. Nonetheless, the multilevel and pluralistic approach proposed in this paper is still under construction.

Discussing what theories can be used in ICT4D (ICT for development) research, Heeks (2007) proposes a continuum of frameworks of knowledge used in development information technology research to categorize different ways of theorizing, making the following distinction: theory-based work makes clear use of an identified theory, either applying or testing that theory; framework-based work makes use of a framework that explicitly derives from a body of theoretical work. We believe that our work fits with the second type and, recalling the Brazilianity debate, the conceptual framework presented benefits from what comes from outside, but is progressively gaining a different, and original, Brazilian flavor. In the coming years, it might contribute to promising opportunities for Brazilian researchers to increase their presence in international outlets, enabling them to finally be in a position to give global exposure to their own views and perspectives on their past and contemporary contexts, reversing the long tradition of having their history told in terms of an external logic. Since any conceptual approach is valid only to the extent to which it is adopted by a significant number of researchers and is validated by relevant empirical analysis, the effective contribution of the proposed framework to the IS research field is still being consolidated.

\section{Received 13 July 2011; received in revised form 3 February 2012.}

\section{References}

Ahmad, A. (2011). Rising of social network websites in India. International Journal of Computer Science and Network Security, 11(2), 155-158. 
Argyris, C., \& Schon, D. (1978). Organizational learning. Englewood Cliffs, NJ: Prentice-Hall.

Augustsson, N., Nilsson, A., \& Holmström, J. (2010, December). The role of context in managing information infrastructure services. Proceedings of the International Conference on Information Systems, Saint Louis, MO, USA.

Avgerou, C. (2008). Information systems in developing countries: a critical research review. Journal of Information Technology, 23(3), 133-146. doi: 10.1057/palgrave.jit.2000136

Avgerou, C., Ganzaroli, A., Poulymenakou, A., \& Reinhard, N. (2009). Interpreting the trustworthiness of government mediated by information and communication technology: lessons from electronic voting in Brazil. Information Technology for Development, 15(2), 133-148. doi: 10.1002/itdj. 20120

Bada, A., Aniebonam, M. C., \& Owei, V. (2004). Institutional pressures as sources of improvisations: a case study from a developing country context. Journal of Global Information Technology Management 7(3), 27-44.

Barbosa, A. (2008). Governo eletrônico: dimensões da avaliação de desempenho na perspectiva do cidadão (Doctoral thesis). Fundação Getúlio Vargas, São Paulo, SP, Brazil.

Barrett, M., \& Walsham, G. (1999). Electronic trading and work transformation in the London insurance market. Information Systems Research, 10(1), 1-21. doi: 10.1287/isre.10.1.1

Bartis, E., \& Mitev, N. (2008). A multiple narrative approach to information systems failure: a successful system that failed. European Journal of Information Systems, 17(2), 112-124. doi: 10.1057/ejis.2008.3

Bartunek, J. M. (1984). Changing interpretive schemes and organizational restructuring: the example of a religious order. Administrative Science Quarterly, 29(3), 355-372.

Bartunek, J. M., \& Moch, M. (1987). First order, second order, and third order change and organization development interventions: a cognitive approach. Journal of Applied Behavior Science, 23(4), 483-500. doi: 10.1177/002188638702300404

Berger, P. L., \& Luckmann, T. (1967). The social construction of reality: a treatise on the sociology of knowledge. Garden City: NY: Anchor.

Bijker, W. E., \& Law, J. (1992). Shaping technology/building society: studies in socio-technical change. Cambridge, MA: MICT Press.

Birochi, R. (2011). Uma abordagem crítica para a educação a distância orientada para as microfinanças (Doctoral thesis). Fundação Getúlio Vargas, São Paulo, SP, Brazil.

Burton-Jones, A., \& Gallivan, M. J. (2007). Toward a deeper understanding of system usage in organizations: a multilevel perspective. MIS Quarterly, 31(4), 657-679.

Caldas, M., \& Wood, T., Jr. (1997). For the English to see: the importation of managerial technology in late 20th-century Brazil. Organization, 4(4), 517-534. doi: 10.1177/135050849700400410

Cernev, A. K. (2010). Mobile banking no Brasil: eventos críticos, trajetória e cenários esperados. (Doctoral thesis). Fundação Getúlio Vargas, São Paulo, SP, Brazil.

Ciborra, C. (1999). Notes on improvisation and time in organizations. Accounting, Management \& Information Technologies, 9(2), 77-94. doi: 10.1016/S0959-8022(99)00002-8

Ciborra, C., \& Willcocks, L. (2006). The mind or the heart? It depends on the (definition of) situation. Journal of Information Technology, 21(3), 129-140. 
Clausen, C., \& Koch, C. (1999). The role of space and occasions in the transformation of information technologies - Lessons from the social shaping of ICT systems for manufacturing in a Danish context. Technology Analysis and Strategic Management, 11(3), 463-482. doi: 10.1080/095373299107456

Comitê Gestor da Internet no Brasil. (2010). Pesquisa sobre o uso das tecnologias da informação e da comunicação no Brasil: TIC LANHOUSES - 2010. Núcleo de informação e coordenação do ponto BR. São Paulo: Comitê Gestor da Internet no Brasil.

Cunha, M. A., \& Pozzebon, M. (2009, September). O uso das tecnologias da informação e comunicação para melhoria da participação na tomada de decisão pública. Proceedings of the Encontro Nacional da Associação Nacional de Pós-Graduação e Pesquisa em Administração, São Paulo, SP, Brazil, 33.

Dagnino, R. (2006). Tecnologia social: retomando o debate. Espacios, 27(2), 18-23.

Dagnino, R. (2009). Technologia social: ferramenta para construir outra sociedade. Campinas: Unicamp.

DaMatta, R. (1989). O que faz o Brasil, Brasil (3rd ed.). Rio de Janeiro: Rocco.

Davidson, E. (2002). Technology frames and framing: a socio-cognitive investigation of requirements determination. MIS Quarterly, 26(4), 329-358.

Davidson, E. (2006). A technological frames perspective on information technology and organizational change. The Journal of Applied Behavioral Science, 42(1), 23-39. doi: $10.1177 / 0021886305285126$

Dawson, P., Clausen C., \& Nielsenet, K. T. (2000). Political processes in management, organization and the social shaping of technology. Technology Analysis and Strategic Management, 12(1), 515. doi: 10.1080/095373200107201

Delgado, N. A., \& Pozzebon, M. (2010, August). Social use and consequences of PGIS in local communities: a structurationist analysis of Sierra Nevada Project. Proceedings of the American Conference on information Systems, Lima, Peru, 16.

Diniz, E., Birochi, R., \& Pozzebon, M. (2010, July). Financial inclusion through correspondents: the case of amazonian autazes. Proceedings of the European Group for Organizational Studies Colloquium, Lisbon, Portugal, 26.

Diniz, E., Pozzebon, M., \& Jayo, M. (2007b, May). Microcredit and correspondent banking in Brazil: what is missing? Proceedings of the IFIP 9.4 International Conference on Social Implications of Computers in Developing Countries, Sao Paulo, Brazil, 9.

Diniz, E., Pozzebon, M., \& Jayo, M. (2007a, August). Microcredit delivery through banking Correspondents in Brazil. Proceedings of the Academy of Management Conference, Philadelphia, Pennsylvania, US.

Diniz, E., Pozzebon, M., \& Jayo, M. (2008, December). Banking technology to scale microfinance: the case of correspondent banking in Brazil. Proceedings of the International Conference on Information Systems, Paris, France.

Diniz, E., Pozzebon, M., \& Jayo, M. (2009b, July). Social innovations in the Brazilian banking area: using correspondents to increase microcredit delivery. Proceedings of the European Group for Organizational Studies Colloquium, Barcelona, Spain, 25. 
Diniz, E., Pozzebon, M., \& Jayo, M. (2009a). The role of ICT in helping parallel paths to converge: microcredit and correspondent banking in Brazil. Journal of Global Information Technology Management, 12(2), 80-103.

Eden, C. (1992). On the nature of cognitive maps. Journal of Management Studies, 29(3), 261-265. doi: 10.1111/j.1467-6486.1992.tb00664.x

Federação Brasileira de Bancos. (2010). Setor bancário em números. Retrieved from http://www.febraban.org.br/Acervo1.asp?id_texto=214\&id_pagina=85\&palavra

Figueiredo, R. S. (2009). A definição do padrão de TV digital no Brasil: um estudo sobre a construção social de um padrão tecnológico (Master dissertation). Fundação Getúlio Vargas, São Paulo, SP, Brazil.

Fischer, T., Roesch, S., \& Melo, V. P. (2006). Gestão do desenvolvimento territorial e residência social. Salvador: EDUFBA.

Gabarra, E. M. (2011). MVNO no Brasil: perspectivas de longo prazo (Master dissertation). Fundação Getúlio Vargas, São Paulo, SP, Brazil.

Gallivan, M. J. (1996). Contradictions among stakeholder assessments of a radical change initiative: a cognitive frames analysis. In W. J. Orlikowski, G. Walsham, M. Jones, \& J. I. DeGross, (Eds.), Information technology and changes in organizational work. Proceedings of the IFIP 8.2 Working Group Conference (pp. 107-130). New York: Chapman \& Hall.

Giddens, A. (1984). The constitution of society. Berkeley, CA: University of California Press.

Goffman, I. (1974). Frame analysis. New York: Harper and Row.

Heeks, R. (2007). Theorizing ICT4D research. Information Technologies and International Development, 3(3), 1-4.

Heracleous, L., \& Barrett, M. (2001). Organizational change as discourse: communicative actions and deep structures in the context of information technology implementation. Academy of Management Journal, 44(4), 755-778.

Heracleous, L., \& Marshak, R. J. (2004). Conceptualizing organizational discourse as situated symbolic action. Human Relations, 57(10), 1285-1312. doi: 10.1177/0018726704048356

Hidalgo, F. D. (2010). Digital democracy: the consequences of electronic voting technology in Brazil. Retrieved from http://qssi.psu.edu/files/hidalgo.pdf

Instituto de Tecnologia Social. (2011). ITS BRASIL 10 anos. Retrieved from http://www.itsbrasil.org.br/

Jayo, M. (2010). Correspondentes bancários como canal de distribuição de serviços financeiros: taxonomia, histórico, limites e potencialidades dos modelos de gestão de redes (Master dissertation). Fundação Getúlio Vargas, São Paulo, SP, Brazil.

Jones, M. R., \& Karsten, H. (2008). Giddens's structuration theory and information systems research. MIS Quarterly, 32(1), 127-157.

Karyda, M., Kiountouzis, E., \& Kokolakis, S. (2005). Information systems security policies: a contextual perspective. Computers \& Security, 24(3), 246-260. doi: 10.1016/j.cose.2004.08.011

King, C. (Ed.). (2009). Brazilian science on the rise. Science Watch. Retrieved from http://sciencewatch.com/ana/fea/09julaugFea/ 
Klein, H. K., \& Myers, M. D. (1999). A set of principles for conducting and evaluating interpretive field studies in information systems. MIS Quarterly, 23(1), 67-99. doi: 10.2307/249410

Koch, C. (2000). Collective influence on information technology in virtual organizations emancipatory management of technology. Technology Analysis and Strategic Management, 12(3), 357-368. doi: 10.1080/713698475

Lavoie, F. (2010). Conditions facilitating the transferability of microcredit methodologies: the case of crediamigo (Master dissertation). HEC Montreal, Montreal, QC, Canada.

Lavoie, F., \& Pozzebon, M. (2010, August). Challenges for inclusive finance expansion: the Case of CrediAmigo, a Brazilian MFI. Proceedings of the Academy of Management Conference, Montréal, Canada.

Lavoie, F., Pozzebon, M., \& Gonzalez, L. (2011). Challenges for inclusive finance expansion: the case of CrediAmigo, a Brazilian MFI. Management International, 15(3), 57-69.

Leal, O. F., \& Souza, R. H. V. (2010). Do regime de propriedade intelectual: estudos antropologicos. Porto Alegre: Tomo Editorial.

Lemos, R., \& Castro, O. (2008). Techno-brega: o para reinventando o negocio da música. Rio de Janeiro: Aeroplano.

Lemos, R., \& Martini, P. (2010). LAN Houses: a new wave of digital inclusion in Brazil [Special Issue]. Information Technologies \& International Development, 6, 31-35.

Lin, A., \& Silva, L. (2005). The social and political construction of technological frames. European Journal of Infornation Systems, 14(1), 45-59. doi: 10.1057/palgrave.ejis.3000521

Luvizan, S. S. (2009). E-HRM-in-practice: um estudo sobre o uso da tecnologia de RH pelas lentes da prática (Master dissertation). Universidade de São Paulo, São Paulo, SP, Brazil.

MacKenzie, D., \& Wajckman, J. (1999). The social shaping of technology. Philadelphia, PA: Open: Open University Press.

McLoughlin, I., Badham, R., \& Couchman, P. (2000). Rethinking political process in technological change: socio-technical configurations and frames. Technology Analysis and Strategic Management, 12(1), 17-37. doi: 10.1080/095373200107210

McLoughlin, I., \& Harris, M. (1997). Innovation, organizational change and technology. London: Thompson Business Press.

Montealegre, R. (1997). The interplay of information technology and the social milieu. Information Technology and People, 10(2), 106-131. doi: 10.1108/09593849710174977

Moreira, A. A. (2011). Modelos tecnológicos da operação por meio de correspondentes bancários no Brasil, foco nos gestores de rede (Master dissertation). Fundação Getúlio Vargas, São Paulo, SP, Brazil.

Ngwenyama, O. N. (1998). Groupware, social action and organizational emergence: on the process dynamics of computer mediated distributed work. Accounting, Management and Information Technology, 8(2-3), 127-146. doi: 10.1016/S0959-8022(98)00003-4

Nicholson, B., \& Sahay, S. (2001). Some political and cultural issues in the globalization of software development: case experience from Britain and India. Information and Organization, 11(1), 2543. doi: 10.1016/S0959-8022(00)00008-4 
Olesen, K., \& Myers, M. D. (1999). Trying to improve communication and collaboration with information technology: an action research project which failed. Information Technology and People, 12(4), 317-332. doi: 10.1108/09593849910301621

Orlikowski, W. J. (2000). Using technology and constituting structures: a practice lens for studying technology in organizations. Organization Science, 11(4), 404-428. doi: 10.1287/orsc.11.4.404.14600

Orlikowski, W. J., \& Gash, D. C. (1994). Technological frames: making sense of information technology in organizations. ACM Transactions on Information Systems, 12(2), 174-207.

Orlikowski, W. J., \& Hofman, J. D. (1997). An improvisational model for change management: the case of groupware technologies. Sloan Management Review, 33(2), 11-21.

Patton, M. Q. (2002). Qualitative evaluation and research methods. Thousand Oaks, CA: Sage Publications.

Pentland, B. T., \& Feldman, M. S. (2007). Narrative networks: patterns of technology and organization. Organization Science, 18(5), 781-797. doi: 10.1287/orsc.1070.0283

Pettigrew, A. M. (1985). Contextualist research and the study of organizational change processes. In E. Mumford, R. Hirschheim, G. Fitzgerald, \& A. T. Wood-Harper (Eds.), Research methods in information systems (pp. 53-72). New York: North Holland.

Pettigrew, A. M. (1987). Context and action in the transformation of the firm. Journal of Management Studies, 24(6), 649-670. doi: 10.1111/j.1467-6486.1987.tb00467.x

Pettigrew, A. M. (1990). Longitudinal field research on change: theory and practice. Organization Science, 1(3), 267-292.

Pinch, T. F., \& Bijker, W. E. (1984). The social construction of facts and artifacts: or how the sociology of science and the sociology of technology might benefit each other. Social Studies of Science, 14(3), 399-441.

Pozzebon, M., Diniz, E. H., \& Jayo, M. (2009). Adapting the structurationist view of technology for studies at the community/societal levels. In Y. K. Dwivedi (Ed.), Handbook of research on contemporary theoretical models in information systems (pp. 18-33). New York: IGI Publishing.

Pozzebon, M., Diniz, E., \& Reinhardt, N. (2011). Creating a brazilian school in international IS research: opportunities and challenges. Revista de Administraçao de Empresas, 51(1), 10-14. doi: $10.1590 /$ S0034-75902011000100002

Pozzebon, M., \& Pinsonneault, A. (2005). Challenges in conducting empirical work using structuration theory: learning from it research. Organization Studies, 26(9), 1353-1376. doi: $10.1177 / 0170840605054621$

Pozzebon, M., Tello-Rozas, S., \& Delgado, N. A. (2012). ICT helping to connect local communities to their natural resources: the case of participatory GIS in Sierra Nevada, Mexico [Working paper $\mathrm{N}^{\mathrm{o}}$ 2012-2]. Groupe de Recherche Interdisciplinaire en Développement Durable, HEC Montreal, Montreal, CA.

Putnam, R. D. (2000). Bowling Alone: The collapse and revival of American community. New York: Simon and Schuster.

Ranson, S., Hinings, B., \& Greenwood, R. (1980). The structuring of organizational structures. Administrative Science Quarterly, 25(1) 1-17. 
Regalado, A. (2010). Brazilian science: riding a gusher. Science, 3.330(6009), 1306-1312. doi: 10.1126/science.330.6009.1306

Rezende, S. M. (2011). Produção científica e tecnológica no Brasil: conquistas recentes e desafios para a próxima década [Pensata]. Revista de Administração de Empresas, 51(2), 202-209. doi: 10.1590/S0034-75902011000200007

Saccol, A., Manica, A., \& Elaluf-Calderwood, S. (2011). Innovation and adoption of mobile technology in public organizations: the IBGE case [Forum]. Revista de Administração de Empresas, 51(1), 72-83. doi: 10.1590/S0034-75902011000100007

Sahay, S. (1998). Implementation of GIS technology in India: some issues of time and space. Accounting, Management and Information Technologies, 8(2-3), 147-188. doi: 10.1016/S09598022(98)00002-2

Sahay, S., \& Robey, D. (1996). Organizational context, social interpretation, and the implementation and consequences of geographic information systems. Accounting, Management and Information Technology, 6(4), 255-282. doi: doi.org/10.1016/S0959-8022(96)00006-9

Silva, L. (2002). Outsourcing as an Improvisation: a case study in Latin America. Information Society, 18(2), 129-138. doi: 10.1080/01972240290075057

Silva, L., \& Westrup, C. (2009). Development and the promise of Technological Change. Information Technology for Development, 15(2), 59-65. doi: 10.1002/itdj.20118

Silva, L. A. da, \& Gushiken, Y. (2010). Lan house: novos mapas de acesso digital na cidade de Cuiabá. Conexão - Comunicação e Cultura, 9(18), 75-88.

Walsham, G. (1993). Interpreting information systems in organizations. Cambridge, MA: John Wiley and Sons.

Walsham, G. (2002). Cross-cultural software production and use: a structurational analysis. MIS Quarterly, 26(4), 359-380. doi: 10.2307/4132313

Walsham, G., \& Sahay, S. (1999). GIS for district-level administration in India: problems and opportunities. MIS Quarterly, 23(1), 39-56. doi: 10.2307/249409

Walsham, G., \& Sahay, S. (2006). Research on information systems in developing countries: Current landscape and future prospects. Information Technology for Development, 12(1), 7-24.

Webshoppers. (2011). Relatório de pesquisa da Câmara Brasileira de Comércio Eletrônico (24th ed.). Retrieved from http://www.webshoppers.com.br/webshoppers/WebShoppers24.pdf

Weick, K. (1993). The collapse of sensemaking in organizations: the mann gulch disaster. Administrative Science Quarterly, 38(4), 268-282.

Williams, R. (1997). Universal solutions or local contingencies? Tensions and contradictions in the mutual shaping of technology and work organization. In I. McLoughlin \& D. Mason (Eds.), Innovation organization change and technology (pp. 170-185). London: International Thomson Business Press.

Wilson, M., \& Howcroft, D. (2005). Power, politics and persuation in IS evaluation: a focus on 'relevant social groups'. Journal of Strategic Information Systemz, 14(1), 17-43. doi: 10.1016/j.jsis.2004.11.007

Yokomizo, C. A. (2009). O papel das tecnologias de informação e comunicação na oferta de serviços financeiros para a população de baixa renda: o caso dos correspondentes bancários do Banco Lemon (Master dissertation). Fundação Getúlio Vargas, São Paulo, SP, Brazil. 
Yokomizo, C. A., Diniz, E. H., \& Pozzebon, M. (2009, December). Financial services to lower income population through the correspondent banking technology: lessons from the Brazilian experience at Banco Lemon. Proceeding of the European International Business Academy Annual Conference, EIBA, Valencia, Spain, 35.

Yunus M., Moingeon, B., \& Lehmann-Ortega L. (2010). Building social business models: lessons from the grammen experience. Long Range Planning, 43(2-3), 308-325. doi: 10.1016/j.lrp.2009.12.005 